A N N A L E S

U N IVERSITATIS MARIAE C URIE-SK七O D OW S K A

L UBLIN - POLONIA

VOL. LXXIII

SECTIO B

2018

EDYTA SAMOJEDNA

ORCID ID 0000-0002-4310-055X

Wydział Nauk o Ziemi i Gospodarki Przestrzennej

Uniwersytet Marii Curie-Skłodowskiej

edyta.samojedna@gmail.com
GRZEGORZ JANICKI

ORCID ID 0000-0003-0731-7898

Wydział Nauk o Ziemi i Gospodarki Przestrzennej

Uniwersytet Marii Curie-Skłodowskiej

grzegorz.janicki@umcs.pl

\title{
Problemy rozwoju lokalnego Starej Kalinowszczyzny (Lublin)
}

Problems of the local development of the Stara Kalinowszczyzna (Lublin)

\begin{abstract}
The paper analyzed the conditions of local development and showed evaluation of the current socio-economic and functional-spatial situation of the historical quarter of the Lublin City so called commonly as Stara Kalinowszczyzna. The main aims of this study was determined potential directions of development of this problem area. Based on the of detailed study (urban inventory, strategic and planning documents analysis, questionnaire research and SWOT analysis) were proposed important activities for further development of this area, such as: activation of inhabitants, improvement of the management status and use of the cultural heritage potential. Stara Kalinowszczyzna has unusual potential resulting from many historical objects, monuments and attractive scenic views of the Old City. Through to appropriate activities aimed at promoting, protecting and improving attractiveness, this area has a chance to become a leading tourist product of the city.
\end{abstract}

Keywords: spatial management, problem area, historical city quarter, SWOT, Poland SE

Abstrakt: W pracy przedstawiono uwarunkowania rozwoju lokalnego oraz ocenę obecnej sytuacji społeczno-ekonomicznej i funkcjonalno-przestrzennej historycznej części dzielnicy Kalinowszczyzna w Lublinie, nazywanej potocznie Starą Kalinowszczyzną. Zasadniczym celem badań było wyznaczenie głównych kierunków rozwoju tego obszaru problemowego. W wyniku przeprowadzonych badań (inwentaryzacja urbanistyczna, analiza dokumentów strategicznych i planistycznych oraz badania ankietowe i analiza SWOT) zaproponowano istotne dla dalszego rozwoju badanego obszaru działania, takie jak: aktywizacja mieszkańców, poprawa stanu zagospodarowania oraz wykorzystanie potencjału dziedzictwa kulturowego. Stara Kalinowszczyzna posiada niezagospodarowany potencjał wynikający z nagromadzenia obiektów historycznych, zabytków oraz atrakcyjnych ekspozycji widokowych na Stare Miasto.

Słowa kluczowe: zagospodarowanie przestrzenne, obszar problemowy, historyczna dzielnica miasta, SWOT, Polska SE 


\section{WPROWADZENIE}

Planowanie przestrzenne jest procesem, który oprócz obecnych potrzeb danego obszaru powinien uwzględniać przyszłe potrzeby różnych grup interesariuszy i odpowiedzieć na nie (Farr 1984; Klasik, Kuźnik 1998; Waldziński 2009). W tym celu konieczne jest szczegółowe i dogłębne rozpoznanie mocnych i słabych stron oraz problemów występujących w sferze społecznej, ekonomicznej, środowiskowej i funkcjonalnej (Heffner 2008). Pozwala to na trafniejsze wyznaczenie celów i kierunków przyszłych działań, tym samym na sprawne zarządzanie rozwojem lokalnym, a co za tym idzie poprawę życia mieszkańców (Wojtasiewicz 1990; Sekuła 2005; Sztando 2017). Narzędziem pomagającym w podejmowaniu ważnych dla społeczności lokalnej działań i decyzji są koncepcje i strategie rozwoju, które stanowią podstawowy element procesu zarządzania strategicznego w jednostkach samorządu terytorialnego (Biniecki, Szczupak 2004; Stachowska 2009; Sztando 2017). W sprawnym zarządzaniu rozwojem ważne jest przeprowadzanie analiz strategicznych, do których należy analiza SWOT, pozwalająca rozpoznać potencjały oraz bariery rozwojowe (Dyson 2002; Asejczyk-Woroniecka 2016). Jednostki decyzyjne mają możliwość wykorzystania mocnych stron obszaru (stymulanty) i niwelacje negatywnych czynników rozwojowych (destymulanty) oraz dostrzeżenia szans, dzięki którym mogą osiągnąć one w przyszłości sukces, jakim jest trwały i zrównoważony rozwój (Dyson 2002).

W przypadku procesu kształtowania historycznego centrum miast polskich lub ich historycznych kwartałów, które uległy degradacji, niezwykle istotne są takie działania rewitalizacyjne, które uwzględniają dziedzictwo kulturowe, tożsamość miejsca oraz zmiany zachodzące po 1989 r. w rozwoju społeczno-gospodarczym (Hełpa-Liszkowska 2013; Kozioł i in. 2013; Murzyn-Kupisz 2013). Konieczność racjonalnego kształtowania przestrzeni i ochrony jej wartości przyrodniczych oraz kulturowych wymaga uwzględnienia również zasad rozwoju zrównoważonego czy ładu przestrzennego (Legutko-Kobus 2016). Natomiast proponowane kierunki rozwoju lokalnego danych jednostek terytorialnych muszą wykorzystywać ich wewnętrzny i zewnętrzny potencjał (Wojtasiewicz 1990; Sekuła 2001, 2005).

W artykule przedstawiono przykład opracowania koncepcji rozwoju lokalnego obszaru tzw. Starej Kalinowszczyzny w Lublinie, na którym występują liczne i zróżnicowane problemy ograniczające jego rozwój. W części pierwszej przedstawiono skróconą diagnozę uwarunkowań społecznych, kulturowych, przestrzennych i ekonomicznych badanego obszaru. Diagnoza ta stanowi kluczowy element w procesie kształtowania rozwoju lokalnego. W drugiej części 
Tab. 1. Wykaz zabytków ujętych w Gminnej ewidencji zabytków miasta Lublin

Tab. 1. List of monuments recorded in the Commune monuments evidence of the Lublin City

\begin{tabular}{|c|c|}
\hline Obiekt wpisany do rejestru / Recorded object & Lokalizacja / Site \\
\hline $\begin{array}{l}\text { Zespół urbanistyczny obejmujący: } \\
\text { - dawny cmentarz żydowski (tzw. Grodzisko) } \\
\text { - Białkowska Góra z terenami przyległymi pomiędzy ulicami Kali- } \\
\text { nowszczyzna, Tatarska i al. Tysiąclecia } \\
\text { - z układem ulic, ukształtowaniem wzgórz, kościołem i klasztorem Sa- } \\
\text { lezjanów (d. Franciszkanów), murem ogrodzenia cmentarza, kamienica } \\
\text { przy ul. Siennej 25, domami nr } 17 \text { i } 19 \text { przy ul. Kalinowszczyzna }\end{array}$ & \\
\hline $\begin{array}{l}\text { Układ urbanistyczny Kalinowszczyzny - Słomiany Rynek i obszaru } \\
\text { ujętego ulicami: Tatarską, Kleeberga, al. Generała Władysława Ander- } \\
\text { sa, al. Tysiąclecia }\end{array}$ & \\
\hline Miejsce straceń więźniów Zamku Lubelskiego & Kalinowszczyzna \\
\hline $\begin{array}{l}\text { Płyta upamiętniająca miejsce egzekucji wmurowana w mur cmentarny } \\
\text { od strony ul. Kalinowszczyzna }\end{array}$ & Kalinowszczyzna \\
\hline Zdrój uliczny & $\begin{array}{l}\text { Kalinowszczyzna } \\
\text { (Słomiany Rynek) }\end{array}$ \\
\hline Kamienica & Kalinowszczyzna 58 \\
\hline Kamienica & Kalinowszczyzna 60 \\
\hline Kamienica - dom mieszkalny & Kalinowszczyzna 37 \\
\hline Garbarnia Silbersteina (Pejsacha Brikmana) & Towarowa 9 \\
\hline Kamienica & Towarowa 13 \\
\hline Kamienica & Towarowa 15 \\
\hline Kamienica & Sienna 25 \\
\hline Ogród klasztorny d. oo. Franciszkanów, ob. oo. Salezjanów & Kalinowszczyzna 3 \\
\hline \multicolumn{2}{|c|}{$\begin{array}{l}\text { Obiekty w kompetencji Wojewódzkiego Konserwatora Zabytków / } \\
\text { Objects under control of Voivodeship Monument Coservator }\end{array}$} \\
\hline Dwór Wincentego Pola, na działce w granicach wg zał. w decyzji planu & Kalinowszczyzna 13 \\
\hline $\begin{array}{l}\text { Zespół klasztorny: } \\
\text { - kościół p.w. MB Wspomożenia Wiernych } \\
\text { - dawny klasztor franciszkański }\end{array}$ & Kalinowszczyzna 3 \\
\hline Dom w gran. posesji & Kalinowszczyzna 19 \\
\hline $\begin{array}{l}\text { Zespół klasztorny poaugustiański: } \\
\text { - kościół parafialny pw. św. Agnieszki } \\
\text { - klasztor } \\
\text { - dzwonnica } \\
\text { - drzewostan w gran. cmentarza kościelnego } \\
\text { - studnia } \\
\text { - dawny szpital pokościelny (ob. dom mieszk. nr 62b) }\end{array}$ & Kalinowszczyzna 62, 62b \\
\hline
\end{tabular}

Źródło: opracowanie własne na podstawie projektu Studium Uwarunkowań i Kierunków Zagospodarowania miasta Lublin, 2018.

Source: own elaboration after the draft of the SUiKZP miasta Lublina (2018). 
pracy przedstawiono uzyskane wyniki badań oraz zaproponowano kierunki działań rewitalizacyjnych.

\section{OBSZAR BADAŃ}

Do szczegółowych badań wybrano fragment dzielnicy Kalinowszczyzna w Lublinie położonej w pobliżu centrum miasta, tzw. Starej Kalinowszczyzny, ponieważ boryka się ona z wieloma problemami, jak m.in.: wysoki poziom ubóstwa i wykluczenie społeczne, degradacja zabudowy, chaos przestrzenny oraz występowanie licznych konfliktów przestrzennych (Program rewitalizacji miasta... 2017). Ten fragment miasta wielokrotnie był uwzględniany w programach rewitalizacji, jednak ich realizacja nie wpłynęła znacząco na poprawę sytuacji Starej Kalinowszczyzny i pomimo dogodnego położenia spełnia swoje
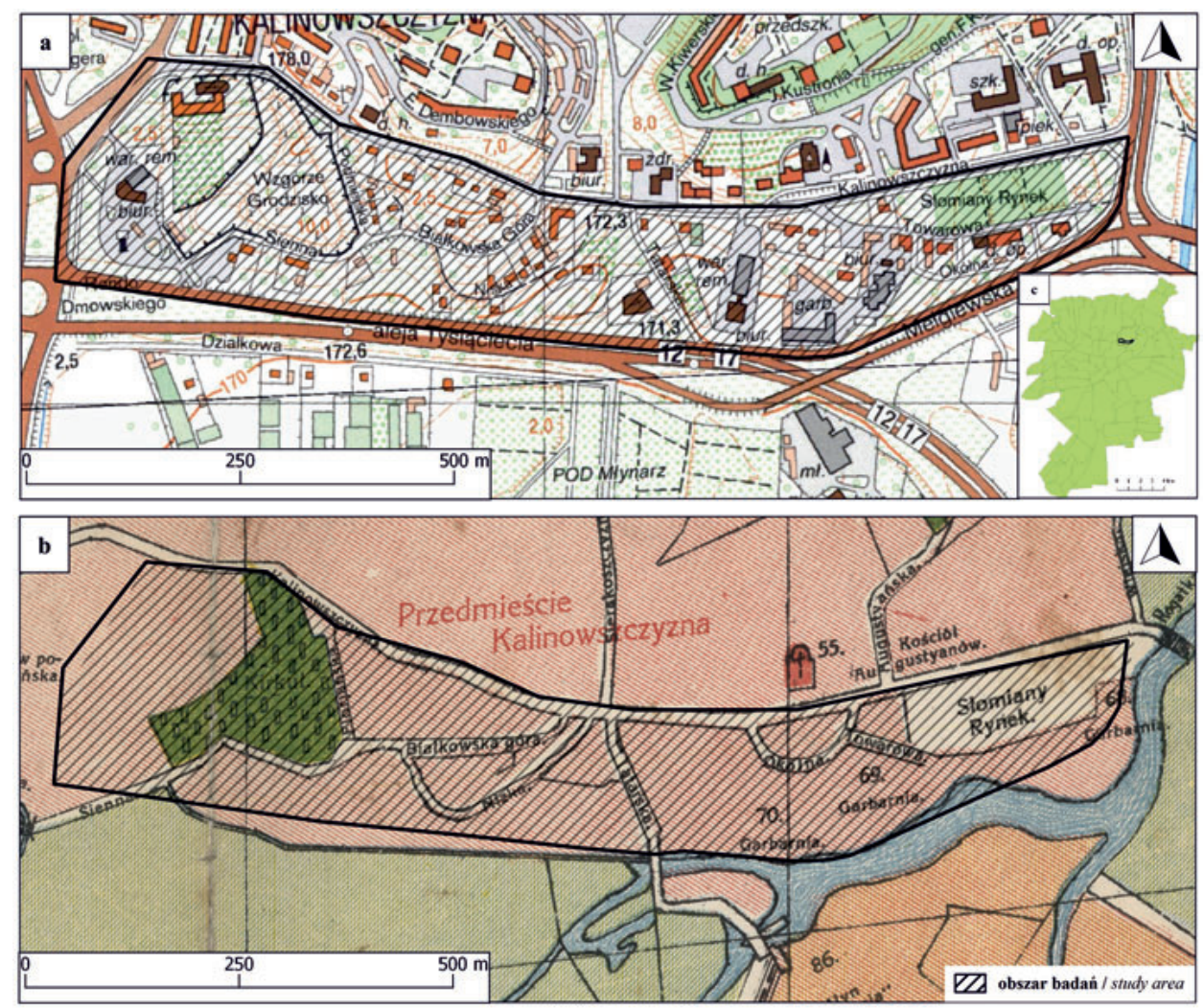

Ryc. 1. Lokalizacja obszaru badań na tle Mapy topograficznej 1: 10000 GUGIK 1992 (a); Planu miasta Lublina 1 : 8400 z 1918 r. (b) oraz na tle podziału miasta Lublina na dzielnice (c) Fig. 1. Location of the research area against the Topographic map 1: 10000 GUGIK 1992 (a) Plan of the Lublin City 1 : 8400 from 1918 year (b) and the division of the Lublin City on quarters (c) 
funkcje tylko w części. Jest to jednocześnie obszar bogaty w obiekty dziedzictwa kulturowego (tab. 1), które dokumentują złożoną historię tego miejsca związaną z początkami osadnictwa na terenie Lublina (dawne Przedmieście Lwowskie) oraz kulturą lubelskich Żydów (Michalczuk 1973; Sochacka 1997). Dawniej był to obszar o dużym znaczeniu dla rozwoju miasta Lublina, dziś jest to raczej obszar zapomniany, który boryka się z wieloma barierami dla jego rozwoju.

Stara Kalinowszczyzna (inaczej Stara Kalina) to fragment dzielnicy Kalinowszczyzna leżącej w obrębie śródmieścia Lublina (ryc. 1). Opisywany obszar obejmuje fragment zbocza lessowego Płaskowyżu Nałęczowskiego, rozczłonkowanego przez rozległy system suchej doliny erozyjno-denudacyjnej, określanej jako „Wąwóz Kalinowszczyzna” (Janicki, Rodzik 2016) oraz niewielką część aluwialnego dna doliny Bystrzycy Lubelskiej (Superson i in. 2018). W topografii tego obszaru wyróżniają się także drugorzędne antropogeniczne formy rzeźby, tj.: Wzgórze Grodziska, na którym znajduje się Stary Cmentarz Żydowski, sąsiednia zabudowana Białkowska Góra oraz obniżenie Słomianego Rynku, dawne centrum handlowe Przedmieścia Kalinowszczyzna (ryc. 1b). Granicę obszaru objętego szczegółowym badaniem stanowią: od jego strony północnej ul. Kalinowszczyzna, której przebieg nawiązuje do historycznego traktu lwowskiego prowadzącego do pobliskiej przeprawy przez rzekę (ryc. 1b), a od południowej strony arterie komunikacyjne $\mathrm{z}$ lat siedemdziesiątych, tj. al. Tysiąclecia oraz ul. Mełgiewska, od wschodu al. Generała Władysława Andersa, a od zachodu

Tab. 2. Stan ludności Starej Kalinowszczyzny według zameldowania na pobyt stały w latach 2002, 2012 i 2017

Tab. 2. Number of habitants in the Kalinowszczyzna according to permanent stay in years 2002, 2012 and 2017

\begin{tabular}{|l|r|r|r|r|}
\hline \multicolumn{1}{|c|}{ Ulica / Streets } & 2002 & 2012 & 2017 & $2002-2017$ \\
\hline Białkowska Góra & 50 & 26 & 26 & -24 \\
\hline Floriańska & 8 & 5 & 7 & -1 \\
\hline Kalinowszczyzna & 953 & 821 & 792 & -161 \\
\hline Niska & 26 & 32 & 30 & +4 \\
\hline Okólna & 4 & 2 & 1 & -3 \\
\hline Sienna & 11 & 11 & 9 & -2 \\
\hline Tatarska & 23 & 19 & 1 & -22 \\
\hline Towarowa & 193 & 176 & 163 & -30 \\
\hline Razem & 1268 & 1092 & 1029 & -239 \\
\hline
\end{tabular}

Źródło: opracowanie własne na podstawie danych Urzędu Miasta w Lublinie.

Source: own elaboration after data from Municipal Office of Lublin City. 


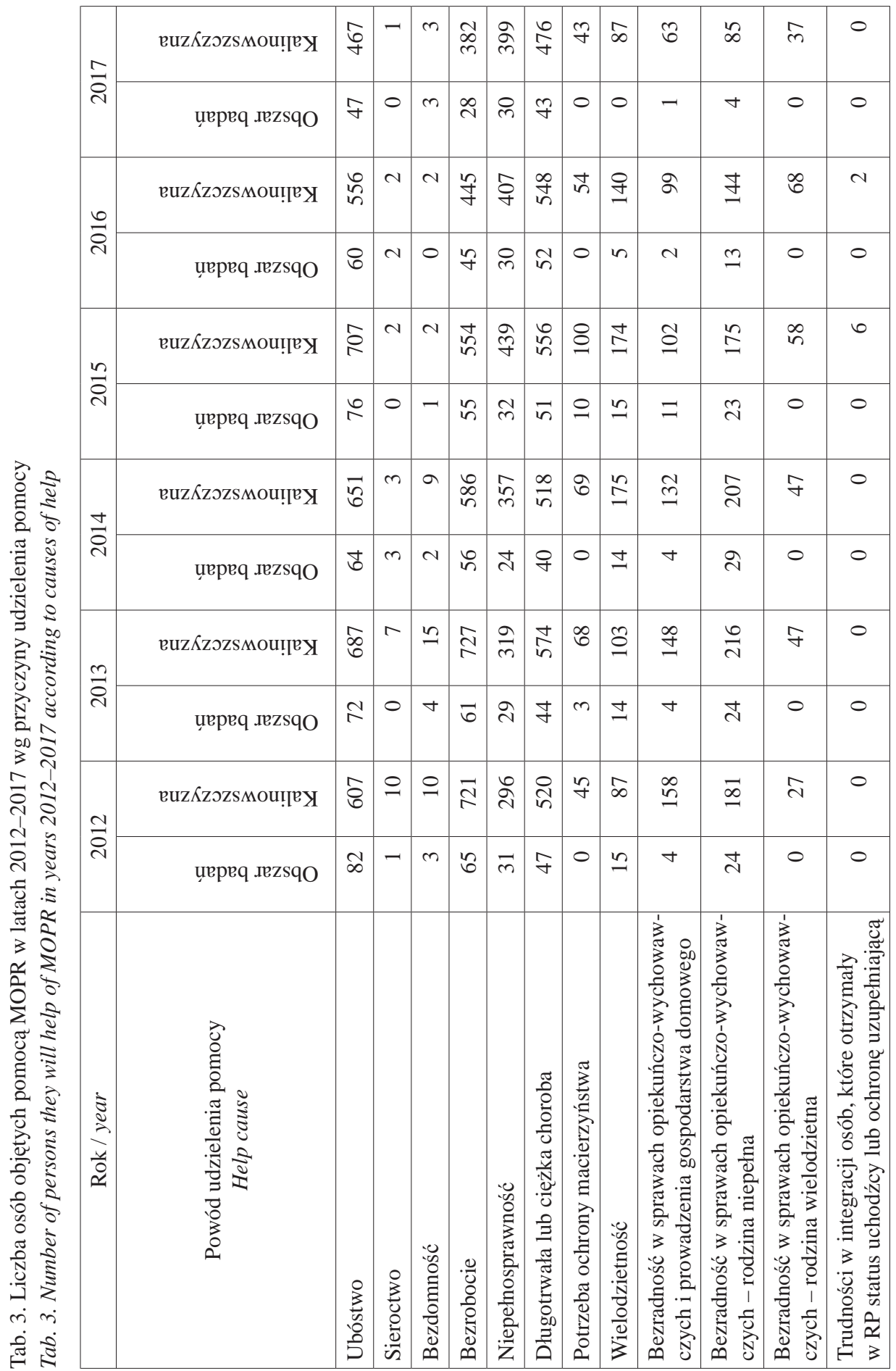




\begin{tabular}{|c|c|c|c|c|c|}
\hline$\widehat{\curvearrowright}$ & 농 & 0 & 0 & $\nabla$ & $\stackrel{\stackrel{m}{m}}{\stackrel{\sim}{\sim}}$ \\
\hline L & 0 & 0 & 0 & -1 & $\begin{array}{l}\infty \\
0 \\
0\end{array}$ \\
\hline$\stackrel{\sim}{N}$ & ำ & -1 & $\underset{\sim}{\nearrow}$ & -1 & $\begin{array}{l}\Re \\
\stackrel{0}{2} \\
\sim\end{array}$ \\
\hline$\nabla$ & 0 & 0 & 0 & 0 & $\vec{\sim}$ \\
\hline$\stackrel{2}{\sim}$ & กิ & -1 & $\mathscr{m}$ & -1 & బิ \\
\hline$m$ & 0 & 0 & 0 & 0 & $\begin{array}{l}\mathscr{N} \\
\stackrel{\sim}{*}\end{array}$ \\
\hline கे & $\widetilde{\sim}$ & -1 & 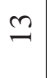 & 0 & $\begin{array}{l}\stackrel{L}{N} \\
\underset{N}{N}\end{array}$ \\
\hline$\nabla$ & $N$ & 0 & $m$ & 0 & $\stackrel{\stackrel{P}{\sim}}{\sim}$ \\
\hline$\approx$ & మ & 0 & $\curvearrowright$ & 0 & $\begin{array}{l}\stackrel{\Omega}{~} \\
\text { ని }\end{array}$ \\
\hline$\sim$ & -1 & 0 & 0 & 0 & $\begin{array}{l}\infty \\
\stackrel{\leftrightarrow}{\sim}\end{array}$ \\
\hline$\stackrel{\sim}{\text { ㄱ. }}$ & छे & -1 & \llcorner & $\stackrel{M}{\rightarrow}$ & 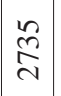 \\
\hline$\sim$ & $\nabla$ & 0 & 0 & -1 & నิ \\
\hline 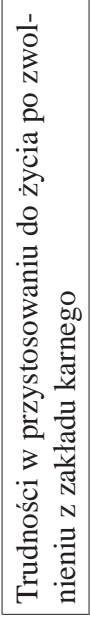 & 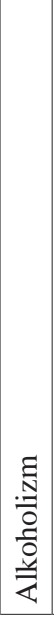 & 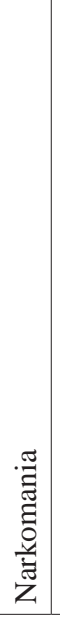 & 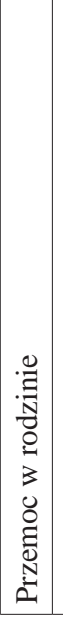 & 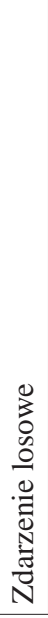 & 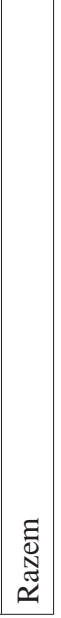 \\
\hline
\end{tabular}


ul. Lwowska (ryc. 1a). Tak wyznaczony obszar zajmuje powierzchnię 25,8 ha, co stanowi $11,71 \%$ powierzchni dzielnicy i około $0,18 \%$ powierzchni miasta (Samojedna 2018).

Od 1989 r. występują tu procesy postępującej degradacji substancji mieszkaniowej oraz problemy demograficzne charakterystyczne dla peryferii miasta. W latach 2002-2017 liczba mieszkańców Starej Kalinowszczyzny zmalała o 239 osób (tab. 2). Liczba zameldowanych osób w 2012 r. w stosunku do roku 2002 zmniejszyła się o około 14\%, natomiast w latach 2012-2017 o około 6\%. W 2014 r. w strukturze wiekowej mieszkańców Starej Kalinowszczyzny dominowała ludność w wieku produkcyjnym (71,04\%), natomiast w wieku przedprodukcyjnym było 19,21\% mieszkańców, a w poprodukcyjnym blisko 10\% (Program rewitalizacji miasta... 2017).

W latach 2012-2015 liczba rodzin otrzymujących wsparcie wzrosła do 125 (z 120 w 2012 r.), jednak od 2016 r. następuje zmniejszenie osób korzystających z pomocy (tab. 2). W 2017 r. na obszarze badań zamieszkiwało 166 (ok. 16,58\%) osób objętych pomocą MOPR. W przypadku Starej Kaliny, podobnie jak dla całej dzielnicy, najliczniejszą grupę stanowiły osoby objęte pomocą z przyczyny ubóstwa. W 2017 r. również duży udział stanowiły rodziny dotknięte problemami długotrwałej lub ciężkiej choroby, bezrobocia czy niepełnosprawności. Natomiast najmniej liczną grupę stanowią osoby borykające się z trudnościami wynikającymi z bezradności w sprawach opiekuńczo-wychowawczych, z bezdomnością czy też wynikającymi z zaistniałych zdarzeń losowych (tab. 3).

Na obszarze Starej Kalinowszczyzny na początku XXI w. obserwuje się znaczny wzrost liczby podmiotów gospodarczych, co jest przejawem pobudzenia aktywności gospodarczej mieszkańców Lublina. W 2007 r. było tu zarejestrowanych nieco ponad 30 podmiotów na 1000 mieszkańców, zaś w 2014 r. stosunek ten wynosił około 45 podmiotów na 1000 mieszkańców (Program rewitalizacji miasta... 2017). Na podstawie przeprowadzonej inwentaryzacji w 2017 r. odnotowano tu 43 podmioty gospodarcze, prowadzące działalność na obszarze badań. Siedziby tych podmiotów koncentrują się głównie w pobliżu ulic: Kalinowszczyzna i Towarowa.

Aktualnie na obszarze badań dominują funkcje mieszkaniowe, z przewagą zabudowy jednorodzinnej (ryc. 2). Tereny zieleni występują głównie w okolicy Słomianego Rynku i Starego Cmentarza Żydowskiego. Oprócz funkcji przyrodniczych analizowany obszar stanowi miejsce rekreacji i odpoczynku dla mieszkańców całej dzielnicy. Podobną funkcję pełni Wąwóz Kalinowszczyzna, będący rozległym terenem zieleni sąsiadującym z obszarem badań. W południowo-wschodniej części Starej Kalinowszczyzny koncentrują się natomiast tereny 


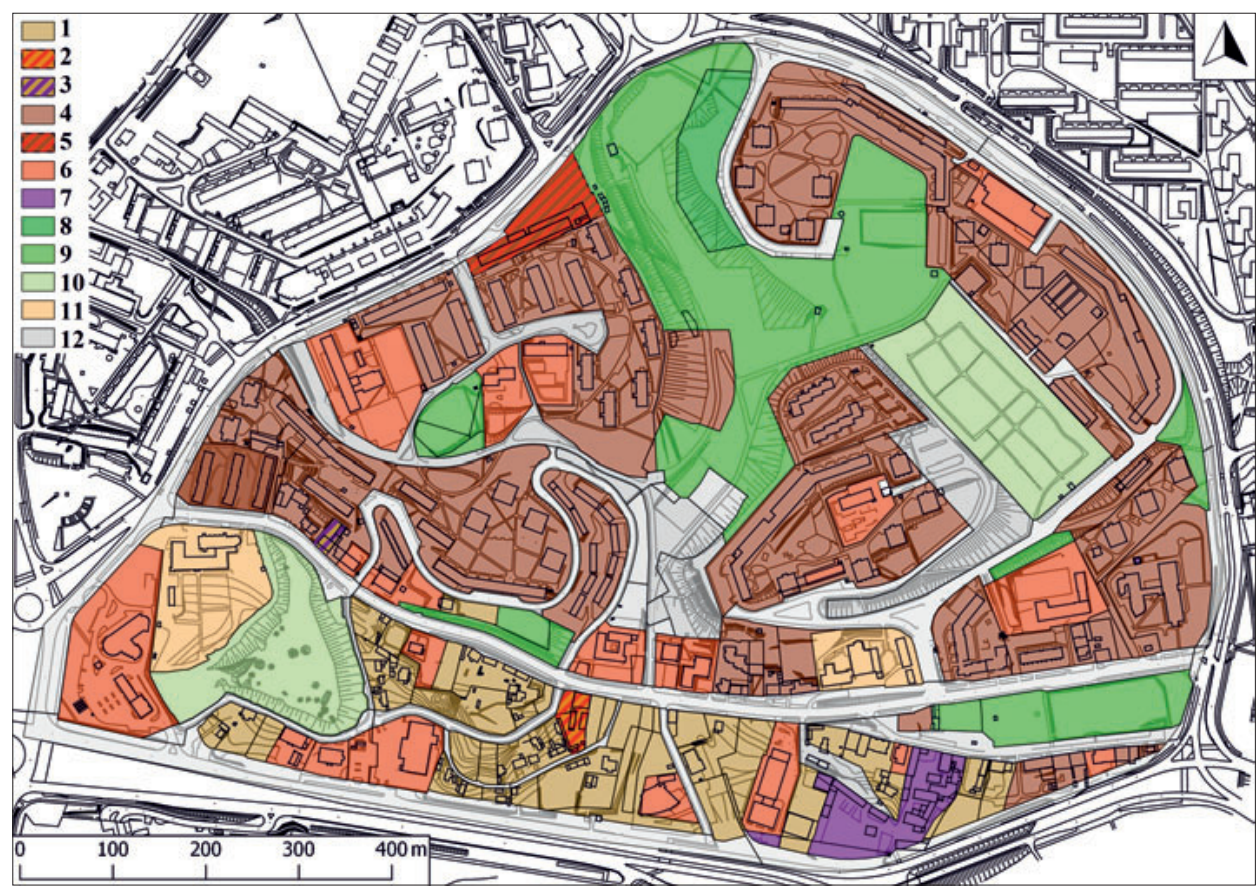

Ryc. 2. Aktualne zagospodarowanie obszaru opracowania i dzielnicy Kalinowszczyzna (opracowanie E. Samojedna): 1. tereny zabudowy mieszkaniowej jednorodzinnej, 2. tereny zabudowy mieszkaniowej jednorodzinnej i tereny usługowe, 3. tereny zabudowy mieszkaniowej jednorodzinnej i tereny produkcyjne, 4. tereny zabudowy mieszkaniowej wielorodzinnej, 5. tereny zabudowy mieszkaniowej wielorodzinnej i tereny usługowe, 6. tereny usługowe, 7. tereny produkcyjne, magazynów, 8. tereny zieleni, 9. tereny zieleni urządzonej, 10. teren cmentarza, 11. tereny obiektów sakralnych, 12. tereny dróg publicznych

Fig. 2. Contemporary spatial management of study area and Kalinowszczyzna Quarter (elaboration by E. Samojedna): 1. an area of a residential one-family houses, 2. an area of a residential one-family and services establishments development, 3. an area of a residential one-family and designated for manufacturing, 4. an area of multi-family houses, 5. an area of multi-family houses and services establishments development, 6. an area of services establishments development, 7. an area of factory grounds, warehouses, 8. green areas, 9. cultivated green areas, 10. green areas - cemeteries, 11. an area of sacred buildings, 12. an area of public service roads

produkcyjne. Tereny usługowe zaś, związane głównie z oświatą, ochroną zdrowia i handlem, są rozproszone (ryc. 2).

\section{METODY BADAŃ}

Prace nad koncepcją rozwoju lokalnego Starej Kaliny przebiegały wieloetapowo i obejmowały: inwentaryzację urbanistyczną, analizę dokumentów strategicznych i planistycznych oraz badania ankietowe i analizę SWOT (ryc. 3). 


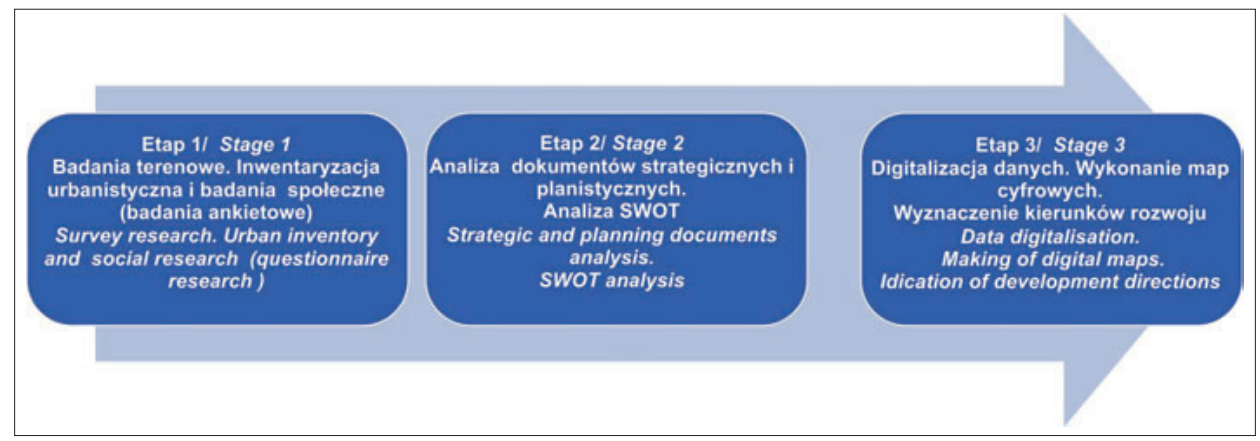

Ryc. 3. Tok postępowania metodycznego (opracowanie E. Samojedna) Fig. 3. Flowchart of work methodology (elaboration by E. Samojedna)

W pierwszym etapie prac w celu identyfikacji występujących na obszarze badań uwarunkowań rozwoju lokalnego przeprowadzono badania terenowe. Inwentaryzacja z wykorzystaniem mapy zasadniczej w skali 1:500 (zasoby Urzędu Miasta Lublina) pozwoliła na ocenę zagospodarowania badanego obszaru i pełnionych przez niego funkcji. Na podkład mapy naniesiono informacje dotyczące: użytkowania poszczególnych działek, miejsc występowania konfliktów przestrzennych, lokalizacji podmiotów gospodarczych i elementów infrastruktury społecznej, a także nowych inwestycji. W trakcie badań terenowych oceniono również walory estetyczne i krajobrazowe obszaru badań, na które wpływ miał: stan zabudowy obiektów mieszkalnych i cennych historycznie, wykorzystanie przestrzeni publicznych oraz ekspozycje widokowe. Dane zebrane w drodze inwentaryzacji urbanistycznej zostały następnie zwektoryzowane przy użyciu oprogramowania ArcMap oraz QGIS, co pozwoliło na prezentację kartograficzną aspektów funkcjonalno-przestrzennych obszaru badań w postaci m.in. mapy zagospodarowania i mapy występowania konfliktów przestrzennych.

Badania społeczne objęły: lokalną społeczność, administrację osiedla Kalinowszczyzna i przedsiębiorców. Wywiady z lokalnymi liderami pozwoliły poznać ich postrzeganie Starej Kaliny i podejmowane inicjatywy gospodarcze. Przeanalizowano również aktywność przedstawicieli dzielnicy oraz jej mieszkańców, sprawdzono listę projektów zgłoszonych w poszczególnych edycjach Budżetu obywatelskiego. Rozpoznano także stosunek mieszkańców do tożsamości miejsca oraz poziom kapitału społecznego. Przeprowadzone w 2018 r. wśród mieszkańców badania ankietowe pomogły określić potrzeby i oczekiwania lokalnej społeczności. W badaniach tych wzięło udział 50 respondentów, z których 82\% zamieszkiwało obszar badań. Część ankiet została przeprowadzona w sposób elektroniczny poprzez narzędzia internetowe. W ramach tych badań respondenci mieli ocenić w skali od 1 (bardzo źle) od 5 (bardzo dobrze) wybrane 
aspekty przestrzeni życiowej Starej Kalinowszczyzny. W efekcie uzyskano ocenę sumaryczną od 50 do 250 punktów dla poszczególnych analizowanych składników życia społeczno-gospodarczego.

W pracy zostały zgromadzone również dane statystyczne informujące o: dziedzictwie kulturowym, sytuacji demograficznej i społecznej, sytuacji ekonomicznej oraz stanie środowiska z instytucji publicznych, takich jak: Urząd Miasta, Miejski Ośrodek Pomocy Rodzinie, Komenda Policji.

W drugim etapem badań przeanalizowano zapisy dokumentów strategicznych i planistycznych (tab. 4). Dokonano również oceny działań prowadzonych przez władze miasta na obszarze badań w sferze funkcjonalno-przestrzennej oraz przeciwdziałania jego degradacji.

Zebrany materiał dokumentacyjny umożliwił określenie potencjałów i barier występujących na terenie badań, przy zastosowaniu kompleksowego i uniwersalnego narzędzia analizy SWOT (Dyson 2002; Asejczyk-Woroniecka 2016). W analizie SWOT wskazano wynikające z uwarunkowań endogenicznych mocne i słabe strony obszaru badań, natomiast uwarunkowania zewnętrzne pozwoliły wskazać szanse i zagrożenia dla jego dalszego rozwoju.

Trzeci etap prac obejmował wskazanie pożądanych działań i potencjalnych kierunków rozwoju Starej Kalinowszczyzny, wyznaczonych na podstawie wykonanych analiz. Na tym etapie wskazana została misja i wizja dla obszaru badań oraz określono i wybrano cele strategiczne. Określono również kierunki

Tab. 4. Wykaz dokumentów strategicznych i planistycznych

Tab. 4. List of planning and strategic documents

\begin{tabular}{|l|c|}
\hline \multicolumn{1}{|c|}{ Dokument / Document } & Źródło / Source \\
\hline $\begin{array}{l}\text { Programu rewitalizacji dla Lublina na lata } \\
\text { 2017-2023 }\end{array}$ & Uchwała Rady Miasta Nr 735/XXIX/2017 \\
\hline Lokalny Program Rewitalizacji dla Lublina 2009 & Uchwała Rady Miasta Nr 752/XXXIII/2009 \\
\hline Lokalny Program Rewitalizacji dla Lublina 2005 & Uchwała Rady Miasta Nr 742/XXXI/2005 \\
\hline Strategia Rozwoju Lublina na lata 2013-2020 & Uchwała Rady Miasta Nr 693/XXVIII/2013 \\
\hline $\begin{array}{l}\text { Studium Uwarunkowań i Kierunków Zagospodaro- } \\
\text { wania 2014 }\end{array}$ & Uchwała Rady Miasta Nr 30/II/2014 \\
\hline $\begin{array}{l}\text { Projekt Studium Uwarunkowań i Kierunków Zago- } \\
\text { spodarowania 2018 }\end{array}$ & \\
\hline $\begin{array}{l}\text { Strategia Rozwiązywania Problemów Społecznych } \\
\text { Miasta Lublin 2014-2020 }\end{array}$ & Uchwała Rady Miasta Nr 1021/XXXIX/2014 \\
\hline Miejscowy Plan Zagospodarowania Przestrzennego & Dz. Urz. Woj. Lub. 2015, poz. 1990 \\
\hline
\end{tabular}

Źródło: opracowanie własne na podstawie danych Urzędu Miasta w Lublinie.

Source: own elaboration after data from Municipal Office of Lublin City. 
działań oraz zidentyfikowane zostały funkcje dla badanego obszaru. Sprawdzono także zgodność przyjętych ustaleń z innymi dokumentami strategicznymi i planistycznymi.

\section{WYNIKI BADAŃ}

\section{Glówne problemy przestrzenne}

Do głównych problemów przestrzennych badanego obszaru należą przede wszystkim: zły stan zabudowy, opuszczone posesje oraz braki w zagospodarowaniu (ryc. 4). Konflikty przestrzenne występują na terenach sąsiadujących z zabytkowym starym kirkutem, gdzie nawet w zapisach planu miejscowego została wyznaczona funkcja usługowa. Również teren kirkutu podlega stałej degradacji, a zgodnie z panującymi w kulturze żydowskiej zasadami w obrębie nekropolii zabronione jest prowadzenie jakichkolwiek prac budowlanych.

Stan obiektów cennych historycznie, jak np. zdrój uliczny na Słomianym Rynku czy budynek mieszkalny przy ul. Kalinowszczyzna 37, jest niezadowalający. Brak opieki i niezbędnych prac renowacyjnych sprawia, że obiekty te popadają w ruinę, a tym samym obszar traci swoje walory kulturowe. Występują tu również zaniedbane lub opuszczone posesje, które znacząco obniżają walory estetyczne otoczenia. Także nieurządzone parkingi wymagają uporządkowania i wyznaczenia bezpiecznych stref parkowania. Natomiast w przypadku objętego ochroną konserwatorską Słomianego Rynku, na którym obecnie znajduje się plac zabaw dla dzieci i niewielki skwer z urządzoną zielenia̧, wymagane są działania

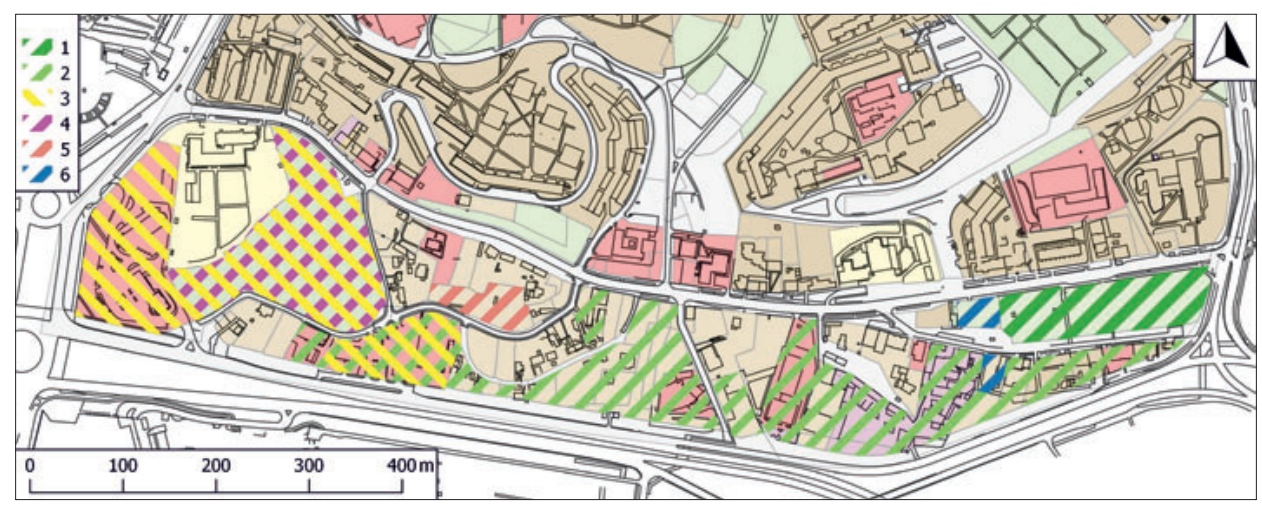

Ryc. 4. Mapa konfliktów i problemów przestrzennych na obszarze badań (opracowanie E. Samojedna): 1. brak miejscowego planu zagospodarowania, 2. konflikt funkcji, 3. konflikt przestrzenny, 4. obiekty problemowe, 5 . opuszczone posesje, 6 . zdegradowana zabudowa

Fig. 4. Map of confl its and spatial problems management in study area (elaboration by E. Samojedna). Maps legend: 1. lack of zoning plans, 2. the function conflicts, 3. the spatial conflicts, 4. the problem object, 5 . the abandoned objects, 6 . the degraded buildings 
pielęgnacyjne i nowe formy zagospodarowania, które wyeksponują w pełni potencjał tego miejsca.

\section{Analiza potencjałów}

Stara Kalina praktycznie w całości nie została objęta planem miejscowym (stan planistyczny miasta Lublin na pierwszy kwartał 2018 r.), nie podjęto również uchwały w sprawie przystappienia do sporządzania miejscowego planu. Miejscowym planem zagospodarowania przestrzennego został objęty jedynie niewielki fragment Starej Kaliny, położony pomiędzy: al. Tysiąclecia, ul. Lwowską a terenami należącymi do klasztoru i kościoła Salezjanów. Według tego dokumentu zaplanowano tu obszar zabudowy usługowej z obszarami zieleni towarzyszącej, natomiast w części północnej obszar szczególnej ochrony walorów przyrodniczych (Dz. Urz. Woj. Lub. 2015, poz. 1990). W obowiązującym Studium uwarunkowań i kierunków zagospodarowania przestrzennego miasta Lublin obszar Starej Kaliny zalicza się do terenów zdegradowanej zabudowy wymagającej programów naprawczych. Teren ten jest również uznawany za silnie zurbanizowany. W zachodniej części obszaru badań znajduje się zaś strefa ochrony konserwatorskiej, gdzie wyznaczono także strefę rozwoju funkcji centrotwórczych.

W ramach działań naprawczych dotyczących kształtowania struktury funkcjonalno-przestrzennej Lublina obszar Kalinowszczyzna - trasa W-Z (jako obszar zaniedbany) oraz osiedle Kalinowszczyzna (jako obszar najbardziej zagrożonej zabudowy wielkopłytowej) zostały objęte programem: Rewitalizacja zaniedbanych obszarów i zespołów mieszkaniowych przeznaczonych do adaptacji. Natomiast w zakresie programu: Rozwój i kształtowanie zróżnicowanych form środowiska mieszkaniowego zaplanowane zostały uzupełnienia tkanki mieszkaniowej w celu otwarcia terenów mieszkalnictwa określonych planem z 1986 i zmianami z 1993. Kalinowszczyzna - trasa W-Z jako obszar zdegradowanej zabudowy został ujęty także w celu wiodącym programu poprawy sfery społecznej: Rewitalizacja zdekapitalizowanej zabudowy mieszkaniowej. W zakresie ochrony środowiska kulturowego za konieczną uznaje się ochronę zespołu Grodziska z Białkowską Górą i Starej Kalinowszczyzny, m.in. ze względu na wartości kulturowe wynikające z faktu, że jest to obszar pierwotnego osadnictwa i historycznego przedmieścia Lublina. Na terenie Starej Kaliny przewidziana jest także lokalizacja Strefy Ochrony Konserwatorskiej Wyjątkowych Wartości Kulturowych Miasta. Natomiast Program ochrony dawnego Przedmieścia Lwowskiego skupia się na zachowaniu elementów historycznej zabudowy i układu urbanistycznego oraz na kształtowaniu krajobrazu harmonijnego (Uchwała Nr 30/II/2014 Rady Miasta Lublin z dnia 23 grudnia 2014 r.). 
W projekcie nowego Studium uwarunkowań i kierunków zagospodarowania przestrzennego dla Lublina z 2018 r. Stara Kalina została zaliczona do rejonu VIII, czyli centralnego. W ramach planowanych tu działań dotyczących kształtowania zorganizowanych osiedli pod uwagę zostały wzięte następujące struktury osadnicze położone w całości na obszarze badań, tj.: osiedle Białkowska Góra, Stara Kalinowszczyzna oraz częściowo: Kalinowszczyzna - os. Lwowska, osiedle Kalinowszczyzna oraz RSM Motor - os. XXX-lecia. W zakresie koncentracji funkcji produkcyjnych, usługowych i składowo-magazynowych w projekcie Studium zostały uwzględnione usługowe tereny przy ul. Lwowskiej i Kalinowszczyzna. Przy ulicach: Kalinowszczyzna, Lwowska, a także cmentarzu rzymskokatolickim przy ul. Kleeberga i żydowskim (Kalinowszczyzna) planuje się również lokalizację elementów struktury osadniczej, takich jak: infrastruktura komunikacyjna i techniczna o znaczeniu ogólnomiejskim i metropolitalnym. Planowane jest także eksponowanie i ochrona dziedzictwa kulturowego, w tym: zespołu urbanistycznego Grodzisko i Białkowska Góra, cmentarza przy ul. Kleeberga i zespołów klasztornych: poaugustiańskiego i selezjanów przy ul. Kalinowszczyzna. W ramach kształtowania i ochrony przestrzeni otwartych oraz terenów tworzących system przyrodniczy miasta wśród kluczowych obszarów, dla których ważne jest zachowanie krajobrazu i powiązań ekologicznych, wymienia się Słomiany Rynek oraz Park Kalinowszczyzna, zlokalizowany w Wąwozie Kalinowszczyzna.

Dzielnica Kalinowszczyzna została uwzględniona także w Lokalnym Programie Rewitalizacji dla Lublina z 2005 r. oraz w jego późniejszej aktualizacji z 2009 r. Również w obowiązującym Programie rewitalizacji dla Lublina na lata 2017-2023 znalazły się zapisy dotyczące Starej Kalinowszczyzny. W dokumencie zauważono, że na tym terenie istnieje wiele problemów społecznych, m.in. bezrobocie czy ubóstwo. Występuje tu także problem z dostępnością komunikacyjna, który wynika z dużego udziału osób niepełnosprawnych wśród mieszkańców i izolacji tego obszaru związanej z przebiegiem al. Tysiąclecia. Obecnie Stara Kalinowszczyzna nie zyskuje na swym położeniu w centrum miasta, co więcej - nie spełnia również znaczącej funkcji względem miasta i regionu. W ramach lokalnego programu rewitalizacji na tym podobszarze wskazano działanie na rzecz trwałego i kompleksowego odwrócenia niekorzystnych zjawisk, powodujących wykluczenie społeczne, oraz wsparcie rozwoju gospodarczego miasta poprzez kapitał kulturowy. Na obszarze badań w obowiązującym programie rewitalizacji przewidziano projekt: Rozbudowa DPS Kalina w Lublinie o nowe specjalistyczne oddziały oraz budowa dwóch rodzinnych domów pomocy społecznej. 


\section{Analiza wyników badań ankietowych}

Wśród osób biorących udział w badaniu ankietowym nieznacznie przeważali mężczyźni (52\% ankietowanych). Według struktury wiekowej największą grupę stanowiły osoby w przedziale wiekowym 18-25 lat (36\% respondentów), a 18\% stanowiła grupa w wieku 26-35 lat, przy zaledwie $4 \%$ udziale ankietowanych $>65$. rok życia. Najwięcej ankietowanych posiadało wykształcenie średnie (34\% osób), a najmniejszą grupę stanowiły osoby z wykształceniem podstawowym (8\%). Wśród respondentów najliczniejszymi grupami były osoby uczące się lub pracujące w przedsiębiorstwach bądź instytucjach. Najwięcej osób zadeklarowało, że ich dochód brutto na 1 osobę miesięcznie wynosi od 1000 do 1500 zł. Tylko 6\% badanych wskazało na dochód powyżej 2000 zł. Wśród ankietowanych osób aż $80 \%$ zadeklarowała zadowolenie z miejsca zamieszkania. Jednak około 40\% ankietowanych deklarowało chęć zmiany miejsca zamieszania na teren poza Starą Kalinowszczyznę, głównie ze względu na brak perspektyw zarobkowych oraz niesatysfakcjonujący standard życia. Wśród osób biorących udział w badaniu ankietowym 38\% zamieszkuje Starą Kalinowszczyznę od 16 do 25 lat, natomiast 8\% respondentów wskazało na czas ponad 45 lat, co dokumentuje trwałość zamieszkania.

Do najsłabiej ocenionych aspektów życia na Starej Kalinowszczyźnie należą: możliwość znalezienia zatrudnienia, warunki mieszkaniowe oraz atrakcyjność obszaru (ryc. 5). Natomiast do najlepiej ocenionych dziedzin życia zalicza się: dostępność transportu zbiorowego, poziom bezpieczeństwa oraz ilość i jakość placówek handlowych (ryc. 6). Dość wysoko respondenci oceniali natomiast elementy infrastruktury technicznej i społecznej. Do najlepiej ocenionych należą: stan infrastruktury kanalizacyjnej, warunki mieszkaniowe oraz dostępność i poziom kształcenia w placówkach oświatowych. Najmniejszą zaś liczbę punktów otrzymały takie elementy, jak: stan dróg i chodników, stan infrastruktury wodociągowej oraz działanie opieki zdrowotnej (ryc. 6).

Według respondentów za priorytetowe działania na rzecz rozwoju Starej Kalinowszczyzny należy uznać: rozbudowę i modernizację dróg, działania na rzecz zapobiegania bezrobociu oraz wspieranie lokalnej przedsiębiorczości (ryc. 7). Do działań o małym znaczeniu ankietowani zaliczyli: zwiększenie ilości i jakości usług komercyjnych, uruchomienie nowych placówek edukacyjnych, prace konserwatorskie, działanie na rzecz ochrony środowiska oraz wzrost zaangażowania mieszkańców w sprawy dzielnicy (ryc. 7).

Należy zauważyć, że ankietowani mieszkańcy Starej Kalinowszczyzny zwykle pozytywnie oceniają warunki życia, a ich ocena znacznie odbiega od raczej negatywnej oceny eksperckiej (Program rewitalizacji miasta... 2017). 


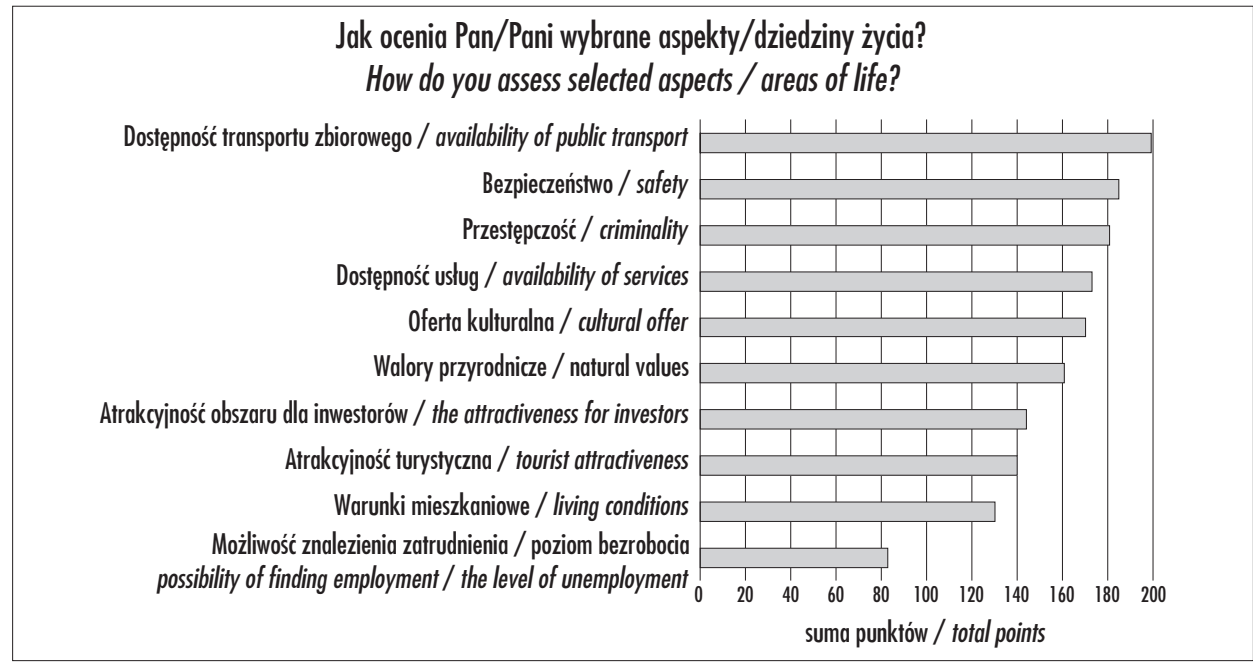

Ryc. 5. Sumaryczna ocena wybranych aspektów życia (opracowanie E. Samojedna)

Fig. 5. Summarized evaluation of selected life aspect (elaboration by E. Samojedna)

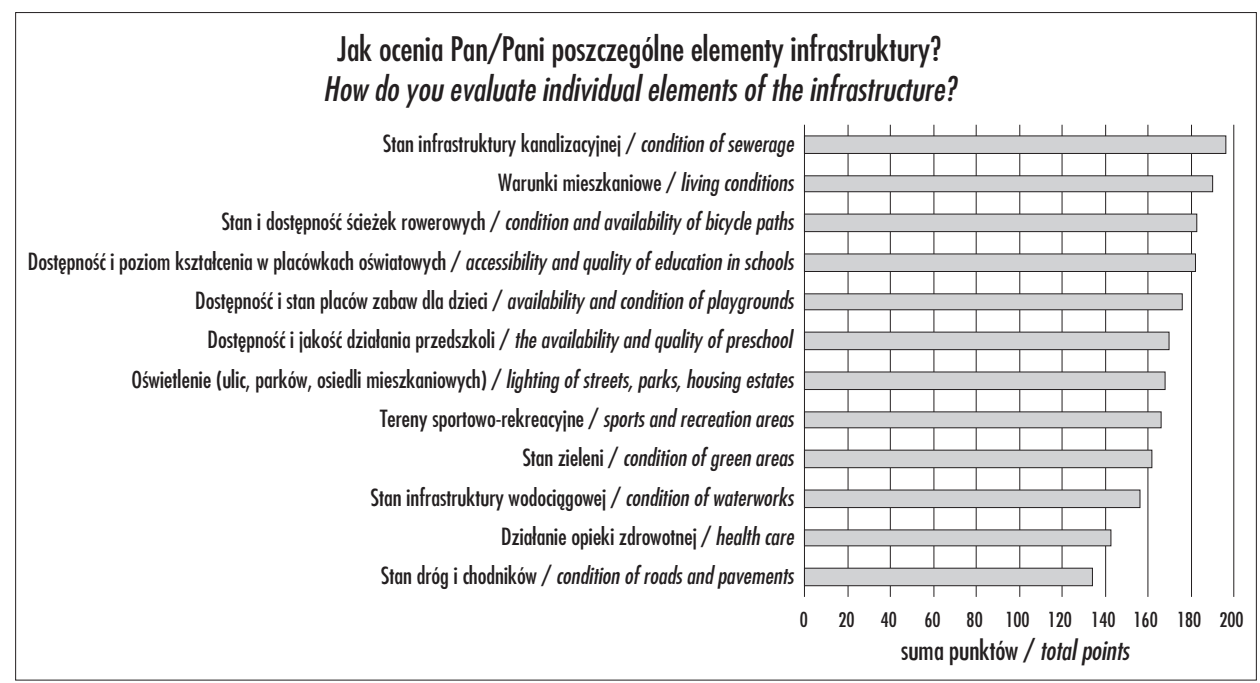

Ryc. 6. Sumaryczna ocena wybranych elementów infrastruktury (opracowanie E. Samojedna) Fig. 6. Summarized evaluation of selected infrastructure elements (elaboration by E. Samojedna)

Według Programu rewitalizacji dla Lublina na lata 2017-2023 co trzeci mieszkaniec wyznaczonego podobszaru rewitalizacji: Kalinowszczyzna dotknięty jest problemem ubóstwa, a co piąty problemem bezrobocia, podczas gdy co siódmy problemem bezrobocia długotrwałego. W przypadku bezrobocia większy wskaźnik posiada jedynie Stare Miasto. W tym podobszarze autorzy LPR identyfikują 


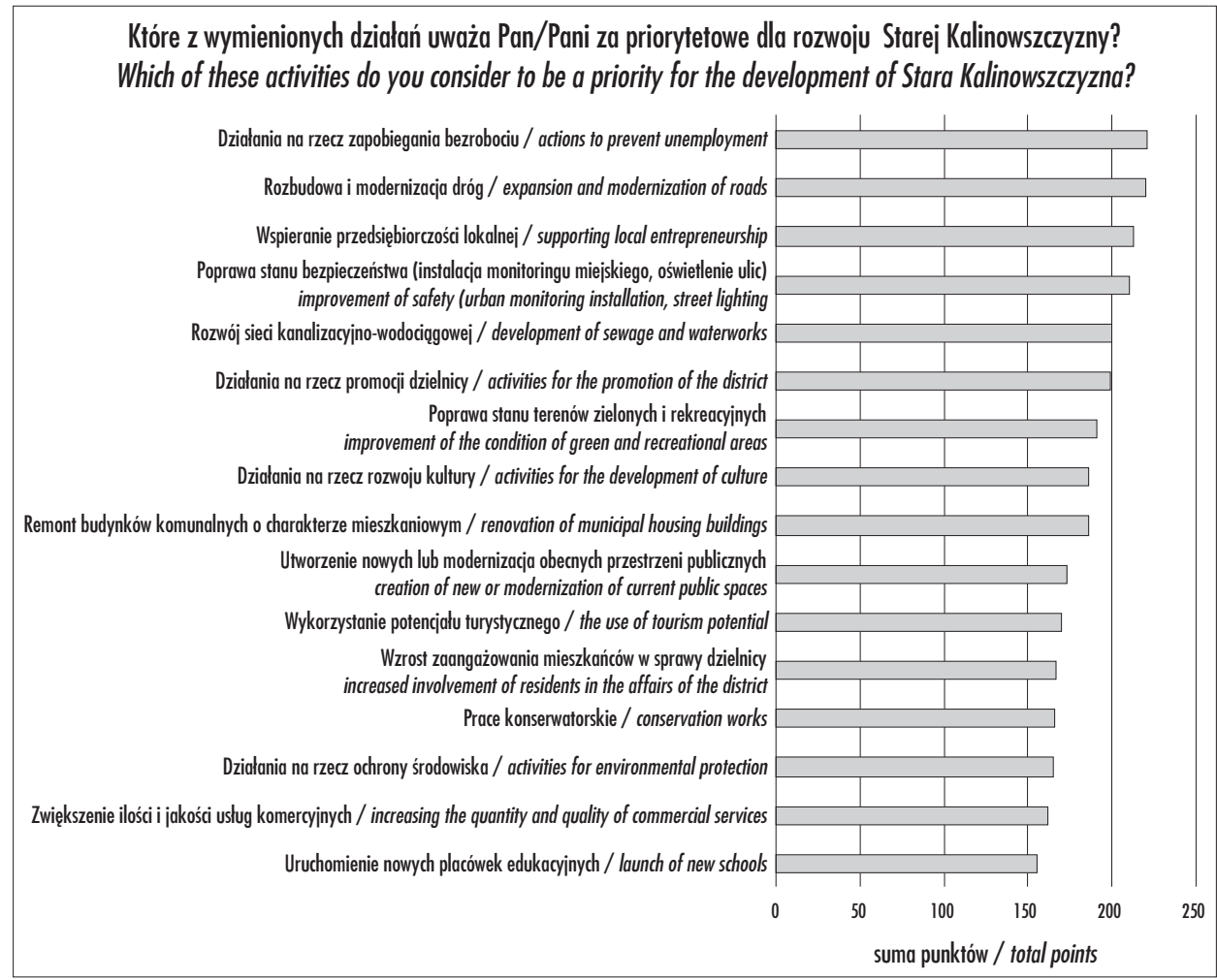

Ryc. 7. Sumaryczna ocena działań priorytetowych dla rozwoju Starej Kalinowszczyzny (opracowanie E. Samojedna)

Fig. 7. Summarized evaluation of priority actions for the Stara Kalinowszczyzna development (elaboration by E. Samojedna)

też inne negatywne zjawiska, m.in.: społeczne, środowiskowe, gospodarcze, techniczne i funkcjonalno-przestrzenne. Podobszar ten ma natomiast znaczny potencjał demograficzny, ponieważ występuje tam duża liczba dzieci i młodzieży, co potwierdzają m.in. statystyki dotyczące pomocy społecznej z powodu wielodzietności, opieki nad dzieckiem. Z drugiej strony sytuacja ta stanowi zagrożenie, ponieważ występuje tu problem ubóstwa, a więc młodzież ta zagrożona jest wykluczeniem społecznym (Program rewitalizacji miasta... 2017).

\section{Analiza SWOT}

Na podstawie przeprowadzonej inwentaryzacji, badań ankietowych oraz zgromadzonych danych o sytuacji społeczno-gospodarczo-funkcjonalnej zostało opracowane tabelaryczne zestawienie wewnętrznych i zewnętrznych uwarunkowań 
Tab. 5. Analiza SWOT

Tab. 5. SWOT analysis

\begin{tabular}{|c|c|}
\hline \multicolumn{2}{|c|}{ Uwarunkowania endogeniczne } \\
\hline mocne strony & słabe strony \\
\hline $\begin{array}{l}\text { Korzystna lokalizacja względem centrum miasta } \\
\text { Cenne zabytki: stary kirkut, kościół pw. św. } \\
\text { Agnieszki, klasztor Salezjanów, dworek Win- } \\
\text { centego Pola } \\
\text { Wąwóz Kalina } \\
\text { Dostępność komunikacyjna (dogodne połą- } \\
\text { czenie komunikacji zbiorowej, bezpośrednie } \\
\text { sąsiedztwo z jedną z głównych ulic miasta); } \\
\text { położenie przy trasie ruchu tranzytowego } \\
\text { Występowanie małej przedsiębiorczości zlokali- } \\
\text { zowanej wzdłuż głównych ulic } \\
\text { Dziedzictwo kulturalne i historyczne (Przedmieście } \\
\text { Lwowskie, Słomiany Rynek, kultura żydowska) } \\
\text { Punkty widokowe na panoramę Starego Miasta } \\
\text { czy dolinę Bystrzycy } \\
\text { Walory krajobrazowe (urozmaicona rzeźba terenu) } \\
\text { Dostępność i dobry standard podstawowej infra- } \\
\text { struktury społecznej (szkoły, żłobki, przychod- } \\
\text { nia, domy pomocy) } \\
\text { Liczne stowarzyszenia działające na tym terenie } \\
\text { Próby integracji mieszkańców (organizacja } \\
\text { festynów, inicjatywy społeczne) } \\
\text { Projekty zgłaszane i realizowane w ramach } \\
\text { budżetu obywatelskiego; aktywność lokalnych } \\
\text { władz i działaczy }\end{array}$ & $\begin{array}{l}\text { Brak planu zagospodarowania przestrzennego } \\
\text { Zły stan techniczny i postępująca degradacja za- } \\
\text { budowy; brak zachowania charakteru zabudowy } \\
\text { nowych inwestycji } \\
\text { Duża liczba osób objętych pomocą społeczną } \\
\text { Występowanie patologii } \\
\text { Zła reputacja dzielnicy zakorzeniona w świado- } \\
\text { mości mieszkańców Lublina } \\
\text { „Dzikie” parkingi } \\
\text { Ograniczenia w użytkowaniu i wykorzystaniu } \\
\text { starego kirkutu wynikające z poglądów religij- } \\
\text { nych } \\
\text { Mała aktywność i współpraca mieszkańców (ni- } \\
\text { ska frekwencja podczas głosowania na lokalne } \\
\text { projekty do budżetu obywatelskiego) } \\
\text { Stan techniczny infrastruktury drogowej, kanali- } \\
\text { zacyjnej i wodociagowej } \\
\text { Srednia i niska zamożność mieszkańców } \\
\text { Nieużytkowane posesje } \\
\text { Odcięcie od centrum ruchliwą al. Tysiąclecia } \\
\text { Duży udział osób niepełnosprawnych } \\
\text { Niechéć do integracji nowo przybyłych miesz- } \\
\text { kańców }\end{array}$ \\
\hline \multicolumn{2}{|c|}{$\begin{array}{ll}\text { Uwarunkowania egzogeniczne } \\
\end{array}$} \\
\hline szanse & zagrożenia \\
\hline $\begin{array}{l}\text { Realizacja założeń programu rewitalizacji } \\
\text { Zwiększenie atrakcyjności turystycznej i inwe- } \\
\text { stycyjnej } \\
\text { Renowacja i poprawa estetyki zabudowy } \\
\text { Aktywizacja lokalnej społeczności } \\
\text { Modernizacja ul. Kalinowszczyzna } \\
\text { Uzupełnienie uzbrojenia terenu } \\
\text { Poprawa dostępności dzielnicy dla osób z nie- } \\
\text { pełnosprawnością } \\
\text { Wykształcenie poczucia lokalnej tożsamości } \\
\text { bazującej na dziedzictwie kulturowym } \\
\text { Opracowanie miejscowego planu; poprawa } \\
\text { jakościowa zagospodarowania } \\
\text { Włączenie w działania kulturalne realizowane } \\
\text { na terenie miasta (np. w obchody Nocy Kultury) } \\
\text { Rozwój Lubelskiego Obszaru Funkcjonalnego } \\
\text { i Lubelskiego Obszaru Metropolitarnego }\end{array}$ & $\begin{array}{l}\text { Brak działań zmierzających do poprawy } \\
\text { obecnej niekorzystnej sytuacji } \\
\text { Utrwalanie niekorzystnego wizerunku Kali- } \\
\text { nowszczyzny } \\
\text { Niekorzystne tendencje demograficzne (starze- } \\
\text { nie się społeczeństwa, odpływ ludzi młodych) } \\
\text { Pogłębianie się patologii społecznych } \\
\text { Postępująca degradacja } \\
\text { Obniżenie poziomu bezpieczeństwa publicznego } \\
\text { Marginalizacja obszaru w stosunku do reszty } \\
\text { miasta } \\
\text { Brak impulsów do rozwoju gospodarczego } \\
\text { Inwestycje niewpisujące się w charakter dziel- } \\
\text { nicy lub wpływające niekorzystnie na walory } \\
\text { krajobrazowe (np. przesłaniające widok na } \\
\text { panoramę Starego Miasta) }\end{array}$ \\
\hline
\end{tabular}

Źródło: opracowanie własne.

Source: own elaboratation. 
rozwoju lokalnego (tab. 5). Dla Starej Kalinowszczyzny głównym czynnikiem stymulującym jej rozwój jest potencjał turystyczny wynikający z lokalnej historii. Natomiast jedną z głównych barier dla jej rozwoju jest zdegradowany krajobraz kulturowy oraz niski poziom kapitału ludzkiego i społecznego (tab. 5).

Najpoważniejszym zagrożeniem dla rozwoju Starej Kalinowszczyzny są jednak niekorzystne tendencje demograficzne, a zwłaszcza starzenie się społeczeństwa oraz odpływ ludzi młodych. Procesy te mogą osłabić aktywność gospodarczą oraz utrudnić odbudowę więzi społecznych czy zachwiać tożsamość mieszkańców. Niewątpliwie szansą dla tego obszaru są działania związane z rozwojem Lublina jako ośrodka ponadregionalnego (Lubelski Obszar Funkcjonalny) oraz metropolitarnego (Lubelski Obszar Metropolitarny), a zwłaszcza rozwój sektora usług metropolitarnych (Samojedna 2018). Aby zapobiegać stagnacji i dalszej degradacji obszaru badań, niezbędne są działania rewitalizacyjne podejmowane przez Urząd Miasta Lublin. Obszar ten wymaga bowiem interwencji z zewnątrz, która pomoże uruchomić wewnętrzny potencjał Starej Kaliny. Ważnym krokiem dla zrównoważonego rozwoju i zapewnienia ładu przestrzennego jest też sporządzenie aktów prawa miejscowego. Konieczna jest również rewitalizacja tkanki społecznej, mająca na celu walkę z wykluczeniem społecznym.

\section{Rekomendacje}

Głównym celem proponowanych działań powinno być przede wszystkim ożywienie społeczne i gospodarcze Starej Kalinowszczyzny, z wykorzystaniem zasobów dziedzictwa kulturowego, oraz poprawa dotychczasowego stanu zagospodarowania (ryc. 8). Dla rozwoju Starej Kaliny ważne są również działania strategiczne, do których należy m.in.: wykorzystanie lokalnego potencjału w celu wzrostu aktywności ekonomicznej i odbudowy kapitału społecznego, poprawa funkcjonalności i jakości zagospodarowania przestrzennego oraz integracja i aktywizacja społeczno-gospodarcza mieszkańców.

Na ryc. 8 przedstawiono kierunki działań, które pozwolą na realizację wyróżnionych celów strategicznych. Działania te obejmują m.in.:

- wykonanie muralu, ponieważ dzieło sztuki zwiększające atrakcyjność miejsca i posiadające walor edukacyjny i artystyczny, przybliża i pokazuje historię miejsca młodym pokoleniom (budowanie tożsamości); jest to też interesujący element przestrzeni, z którym teren ten może być pozytywnie kojarzony przez mieszkańców także innych dzielnic miasta;

- uwydatnienie i ochrona zachowanego historycznego układu ulic poprzez wprowadzenie do przestrzeni elementu wyróżniającego, np. stylizowane latarnie 


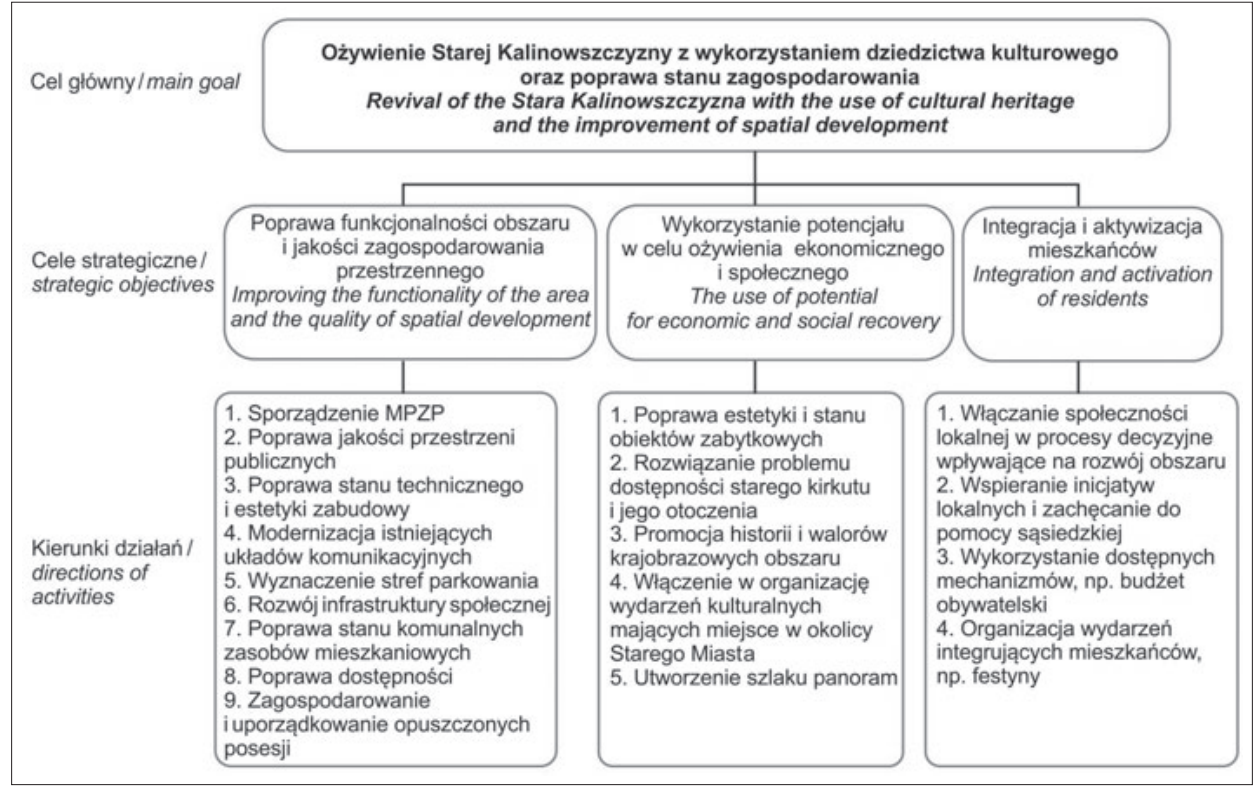

Ryc. 8. Hierarchia celów i kierunki proponowanych działań (opracowanie E. Samojedna)

Fig. 8. Hierarchy of aims and directions of proposed activities (elaboration by E. Samojedna)

lub zaprojektowanie trasy turystycznej, m.in. dla lubelskich konnych dorożek (pomysł członka Rady Miasta);

- utworzenie miejsca spotkań i integracji mieszkańców, np. kawiarnia lub inny lokal gastronomiczny (może z kuchnią żydowską?) - postulat mieszkańców, którzy sygnalizowali brak takiego lokalu gastronomicznego;

- zagospodarowanie Słomianego Rynku poprzez stworzenie przestrzeni do integracji międzypokoleniowej oraz aktywizacji osób starszych i z pobliskiego DPS Kalina;

- dostosowanie przestrzeni publicznych i elementów infrastruktury do potrzeb osób niepełnosprawnych i starszych - zgodnie z lubelskimi standardami pieszymi i zasadami projektowania uniwersalnego;

- realizacja zapisów z MPZP w zakresie zachowania i uzupełniania pierzei Słomianego Rynku.

\section{PODSUMOWANIE I WNIOSKI}

Na podstawie przeprowadzonych badań i analiz uważa się, że aktywizacja mieszkańców i ich zaangażowanie w sprawy lokalne oraz zachęcenie do współpracy są niezbędnymi działaniami prorozwojowymi dla obszaru Starej Kalinowszczyzny. Warto także wspierać budowę kapitału ludzkiego i społecznego mieszkańców, 
który ułatwia prowadzenie racjonalnej polityki przestrzennej. Fundamentem tych działań jest oczywiście przystąpienie do sporządzenia miejscowego planu zagospodarowania przestrzennego oraz realizacja zapisów Programu rewitalizacji miasta Lublina na lata 2017-2023. Poprawa sytuacji w sferze funkcjonalno-przestrzennej może również przyczynić się do trwałego i zrównoważonego rozwoju Starej Kaliny, a tym samym poprawy jakości życia jej mieszkańców. Działania te wpłyną także na lepsze zagospodarowania terenu oraz poprawę estetyki, a co za tym idzie - podniesienie atrakcyjności tego obszaru. Zmiany te są potrzebne, aby móc wykorzystać istniejący potencjał turystyczny Starej Kalinowszczyzny, wynikający z jej historii, tradycji oraz walorów krajobrazowych. W tym celu można włączyć Starą Kalinowszczyznę w wydarzenia kulturowe odbywające się w otoczeniu Starego Miasta (np. obchody Nocy Kultury). Poprawa ekspozycji widokowej i zagospodarowanie punktów widokowych występujących na tym obszarze może być zintegrowana z projektowanym szlakiem panoram miasta Lublina. Pożądane są również działania promujące dziedzictwo kulturowe tego obszaru, m.in. poprzez organizację imprez tematycznych w rodzaju targów nawiązujących do historii dawnego traktu handlowego.

Przeprowadzone badania pozwalają na sformułowanie następujących wniosków:

1. Obszar Starej Kalinowszczyzny boryka się z wieloma problemami społecznymi, jak: ubóstwo czy wykluczenie społeczne. Natomiast w sferze funkcjonalno-przestrzennej są to przede wszystkim: degradacja zabudowy, brak MPZP czy opuszczone posesje.

2. Stara Kalinowszczyna posiada duży potencjał rozwojowy wynikający z dziedzictwa kulturowego oraz atrakcyjnych ekspozycji widokowych na Stare Miasta.

4. Najbardziej istotne dla rozwoju obszaru badań są: aktywizacja i wzrost zaangażowania mieszkańców, wykorzystanie potencjału turystycznego i poprawa stanu zagospodarowania.

3. Postulowana wielofunkcyjność obszaru Starej Kalinowszczyzny może zrealizować się poprzez wprowadzenie nowych funkcji, np. turystycznych czy rekreacyjnych, ale przede wszystkim pożądane są zmiany w zagospodarowaniu przestrzennym.

Wkład indywidualny autorów: Edyta Samojedna - 70\%, Grzegorz Janicki - 30\%. 


\section{LITERATURA}

Asejczyk-Woroniecka M., 2016: Zastosowanie analizy SWOT $w$ doskonaleniu zarzadzania jednostkami administracji terytorialne. Finanse, Rynki Finansowe, Ubezpieczenia, 6, cz. 1, 311-321. DOI: 10.18276/frfu.2016.84/1-27

Biniecki J., Szczupak B., 2004: Strategiczne myślenie o przyszłości gminy. Wydawnictwo Akademii Ekonomicznej w Katowicach, Katowice, 128.

Brdulak J., 2011: Cechy rozwoju lokalnego. Demografia przedsiębiorstw, Konkurencyjność i innowacyjność przedsiębiorstw, http://www.praktycznateoria.pl/cechy-rozwoju-lokalnego/ (dostęp: 16.05.2018).

Buczyński M., 1962: Nazwy dzielnic i przedmieść Lublina, Rocznik Lubelski, t. V.

Czyńsk K., Marzęcki W., Rubinowicz P., 2011: Studium wartości widokowych miasta Lublina, Szczecin, Lublin.

Dyson R.G., 2002: Strategic development and SWOT analysis at the University of Warwick. European Journal of Operational Research, 152, 631-640. Doi:10.1016/S0377-2217(03)00062-6

Farr Ch. (ed.), 1984: Shaping the Local Economy. Current Perspectives on Economic Development. International City Management Association, Washington.

Heffner K., 2008: Strategie rozwoju regionalnego i lokalnego, [w:] Z. Strzelecki (red.), Gospodarka regionalna i lokalna. Wydawnictwo Naukowe PWN, Warszawa, 20-164.

Hełpa-Liszkowska K., 2013: Dziedzictwo kulturowe jako czynnik rozwoju lokalnego. Studia Oeconomica Posnaniensia, 6 (255), 1-18.

Janicki G., Rodzik J., 2014: Rolnicze użytkowanie lubelskich „wąwozów” - erozja gleb i jej zapobieganie, [w:] E. Trzaskowska (red.), Wąwozy i suche doliny Lublina - potencjat i zagrożenia. UM Lublin, 40-54.

Klasik A., Kuźnik F., 1998: Planowanie strategiczne rozwoju lokalnego i regionalnego, [w:] S. Dolata (red.), Funkcjonowanie samorządu terytorialnego - doświadczenia i perspektywy, t. II, Wydawnictwo UO, Opole, 395-396.

Kobyliński Z., 2011: Czym jest, komu jest potrzebne i do kogo należy dziedzictwo kulturowe? MAZOWSZE Studia Regionalne, 7, 21-47.

Kozioł A., Trelka M., Florjanowicz P., 2013: Społeczno-gospodarcze oddziaływanie dziedzictwa kulturowego, Raport z badań spolecznych. Narodowy Instytut Dziedzictwa, Warszawa.

Legutko-Kobus P., 2016: Zarządzanie dziedzictwem kulturowym jako element implementacji rozwoju zrównoważonego na poziomie lokalnym. Prace Naukowe Uniwersytetu Ekonomicznego we Wrocławiu. Rozwój trwały i zrównoważony, 452, 219-228. DOI: 10.15611/pn.2016.452.19

Michalczuk S., 1973: Lubelskie przedmieścia Kalinowszczyzna (I), Kurier Lubelski, 135, 3.

Murzyn-Kupisz M., 2013: Dziedzictwo kulturowe w kontekście rozwoju lokalnego, [w:] J. Hausner, A. Karwińska, J. Purchla (red.), Kultura a rozwój. Narodowe Centrum Kultury, Warszawa, 237-263.

Samojedna E., 2018: Koncepcja rozwoju lokalnego Starej Kalinowszczyzny. Maszynopis. Wydział Nauk o Ziemi i Gospodarki Przestrzennej, UMCS, Lublin.

Sekuła A., 2001: Koncepcje rozwoju lokalnego w świetle współczesnej literatury polskiej - zarys problemu. Zeszyty Naukowe, 588, 89-95. 
Sekuła A., 2005: Bariery rozwoju lokalnego, [w:] B. Filipiak, A. Szewczuka, Z. Zychowicza (red.), Samorzad terytorialny w zintegrowanej Europie. Zeszyty Naukowe, 401, 587-600.

Skubiak B., 2013: Stymulowanie rozwoju w regionie problemowym. Folia Pomeranae Universitatis Technologiae Stetinensis, Oeconomica, 299, 191-200.

Sochacka A., 1997: Rodowody lubelskich dzielnic, [w:] T. Radzik, A. Witusik (red.), Lublin w dziejach i kulturze Polski. Krajowa Agencja Wydawnicza, Lublin.

Superson J., Demczuk P., Reder J., 2018: Regionalne uwarunkowania rozwoju rzeźby terenu Lublina, Annales UMCS, sec. B., 107-124.

Stachowska S., 2009: Planowanie strategiczne w rozwoju lokalnym, [w:] B. Plawgo (red.), Planowanie w zarządzaniu rozwojem lokalnym. Seria Zarządzanie Rozwojem Lokalnym, Fundacja BFKK, Białystok.

Sztando A., 2017: Lokalistyczne cechy zarządzania strategicznego rozwojem lokalnym. Gospodarka lokalna i regionalna w teorii i praktyce. Prace naukowe Uniwersytetu Ekonomicznego we Wrocławiu, 477, 281-04. DOI: 10.15611/pn.2017.477.27.

Waldziński D., 2009: Rola planowania w zarządzaniu rozwojem lokalnym, [w:] B. Plawgo (red.), Planowanie w zarzadzaniu rozwojem lokalnym. Seria Zarządzanie Rozwojem Lokalnym, Fundacja BFKK, Białystok.

Wojtasiewicz L., 1990: Planowanie rozwoju lokalnego, [w:] B. Gruchman, J. Tarajkowski (red.), Rozwój gospodarki lokalnej w teorii i praktyce. Uniwersytet Warszawski - Instytut Gospodarki Przestrzennej, Warszawa, 37-47.

\section{NETOGRAFIA}

Plan miasta Lublina, 1918: Wojskowy Instytut Geograficzny, http://maps.mapywig.org/m/City_ plans/Central_Europe/PLAN_M._LUBLINA_8.4K_1918.jpg (dostęp: 15.05.2018) 